J. Clin. Chem. Clin. Biochem.

Vol. 23, 1985, pp. $381-386$

\title{
Multiple Forms of Angiotensin-Converting Enzyme in Human Tissues and Fluids
}

\author{
By M. van Sande, S. L. Scharpé, H. M. Neels \\ Faculty of Medicine, University of Antwerp, Belgium and

\section{Y. Kasahara}

Fujirebio Inc., Shinzuku, Tokyo, Japan

(Received September 18, 1984/March 1, 1985))

Summary: Angiotensin-converting enzyme (EC 3.4.15.1) exhibits distinctive tissue differences in electrophoretic behaviour. Human tissue homogenates and biological fluids were subjected to agar gel and polyacrylamide gel electrophoresis. The gels were cut into slices and enzymatic activity detected by a specific colorimetric reaction. The technique allows localization of the enzyme in the electrophoretogram and gives an estimate of the total enzymatic activity of a tissue or biological fluid. Several tissues were found to show multiple forms of angiotensin-converting enzyme. The specificity of the assay was determined by running the samples after the addition of captopril and by adding proteinase inhibitors to the incubation mixture.

\section{Multiple Formen von Angiotensin-Converting Enzyme in Geweben und biologischen Flüssigkeiten des Menschen}

Zusammenfassung: Angiotensin-Converting Enzyme (EC 3.4.15.1) weist von Gewebe zu Gewebe deutliche Unterschiede im elektrophoretischen Verhalten auf. Gewebshomogenate und biologische Flüssigkeiten vom Menschen wurden der Agargel- und Polyacrylamidgel-Elektrophorese unterworfen. Die Gele wurden in Scheiben geschnitten und die katalytischẹn Aktivitäten mit einer spezifischen kolorimetrischen Reaktion nachgewiesen. Das Verfahren erlaubt die Lokalisierung des Enzyms im Elektropherogramm und gestattet eine Schätzung der katalytischen Gesamtaktivität in einem Gewebe oder einer biologischen Flüssigkeit. In mehreren Geweben konnten multiple Formen von Angiotensin-Converting Enzyme nachgewiesen werden. Die Spezifität des Verfahrẹens wurde durch vorherige Zugabe von Captopril bzw. Zugabe von Proteaseinhibitoren zum Inkubationsgemisch geprüft.

\section{Introduction}

Angiotensin-converting enżyme (dipeptidyl carboxypeptidase, kininase II, EC 3.4.15.1) is a membrane bound glycoprotein which mediates the cleavage of the dipeptide histidyl-leucine from the decapeptide angiotensin I to generate the octapeptide angiotensin II; it also catalyses bradykinin degradation. The assay of angiotensin-converting enzyme activity in human serum is a useful tool for detecting clinically active pulmonary sarcoidosis and for monitoring ste- roid therapy in this disease (1). Here we describe the electrophoretic behaviour of angiotensin-converting enzyme from human tissue homogenates and biological fluids. Detection of enzyme activity was carried out by a specific two-step colorimetric reaction sequence developed by one of us (2).

Angiotensin-converting enzyme was successfully purified by a combination of chromatographic and electrophoretical techniques. Heterogeneity of the 
purified enzyme has been reported in several cases. Fitz \& Overturf (3) provided evidence for the existence of more than one angiotensin-converting enzyme. The elution pattern (Sephadex G-200) of an ammonium sulphate precipitated preparation of human lung showed two peaks of angiotensin-converting enzyme. The authors suggested that more than one enzyme could be involved in the conversion of angiotensin I, perhaps by causing sequential peptide loss from the $\mathrm{COOH}$-terminal of the molecule.

A 500 -fold purification of converting enzyme from human seminal plasma on Sephadex G-200 also yielded 2 fractions with different molecular weights. Both were inhibited by the nonapeptide SQ 20,881 (4).

Oshima et al. (5) purified angiotensin-converting enzyme from hog kidney by a combination of several chromatographic techniques (DEAE-cellulose, calcium phosphate gel, DEAE-Sephadex A-50, hydroxylapatite, Sephadex G-200) and found in the purified enzyme two protein bands on standard disc electrophoresis. A single protein component was obtained in the gel after treatment with neuraminidase (EC 3.2.1.18). The two bands were both active enzymes, differing only in sialic acid content.

In homogenates of human placenta, Litrowicz \& Malofiejew (6) found, after enzyme filtration on Sephadex G-200, 3 protein peaks of converting enzyme. After purification of converting enzyme from human lung, Grönhagen-Riska \& Fyhrquist (7) showed one major and one faint band. These authors suggested that the different enzymatic peaks in Sephadex elutions represent polymeric forms of the enzyme.

Using polyacrylamide gel electrophoresis, Hara et al. (8) found two peaks of converting enzyme in granulomatous lesions of the skin of patients with beryllium-induced hypersensitivity. Two peaks with the same mobility as those from pathological sources were also found in normal dermis. The aim of the present study was to show the heterogeneity of converting enzyme in crude tissue homogenates, using the capacity to cleave histidyl-leucine from an artifical substrate, as well as inhibition with captopril in low concentrations, as criteria for the definition of the enzyme.

The multiple forms of angiotensin-converting enzyme lend support to the hypothesis of the existence of enzymes with quantitatively different sialic acid con-。 tent in the homogenates and biological fluids studied.

\section{Materials and Methods}

\section{Human material}

Serum was obtained from blood-bank donors, sperm from healthy donors and prostatic fluid from vasectomized individuals. All fluids were frozen in liquid nitrogen and stored at $-87^{\circ} \mathrm{C}$ as rapidly as possible. The following tissues were obtained from surgical patients: prostate (from patients with prostate-carcinoma, or benign prostatic hypertrophy, or normal prostate tissue from patients with bladder cancer), kidney, testis, seminal vesicle, ductus deferens, bladder, stomach (antrum), ileum, appendix, colon transversum, gall bladder, rectum, spleen, vena saphena magna, skin, thyroid, sigmoid, liver, lung, skeletal muscle, ovary and bone marrow. These were frozen as soon as possible in liquid nitrogen and stored at $-87^{\circ} \mathrm{C}$.

\section{Reagents}

Hippuricase (EC 3.5.1.14) and the enzyme substrate, phydroxybenzoyl-glycyl- $L$-histidyl- $L$-leucine were obtained from Fujirebio Inc., Tokyo, Japan. The agar employed (Agar Noble) was obtained from Difco, Detroit, Michigan, USA. Polyacrylamide reagents for disc electrophoresis were from Eastman-Kodak, Rochester, N.Y., USA. Captopril (SQ 14225) was a generous gift from Squibb, Belgium. Nonidet P40 was from L.K.B., Bromma, Sweden. Soybean trypsin inhibitor from Worthington Biochemical Corporation, Freehold, N.J., USA. N-ethyl-maleimide from Aldrich, Milwauky, Wisconsin, pepstatin from Protein Research Foundation, Osako, Japan and aprotinin from Bayer, F.R.G. Octyl- $\beta$ - $D$-glycopyranoside was from Calbiochem-Behring, La Jolla, California, USA. Human albumin was obtained from Sigma Chemicals, St. Louis, Missouri, USA, and Macrodex, a depolymerized dextran $\left(M_{\mathrm{r}} 40000\right)$ was from Povite, Christiaens, Brussels, Belgium. All other reagents were of analytical grade (E. Merck, Darmstadt, F.R.G.).

\section{Tissue homogenization}

Tissue homogenates were prepared by grinding the tissue in an Elvejhem glass homogenizer with a teflon pestle, either by adding one drop of Nonidet $\mathrm{P} 40$ per $200 \mathrm{mg}$ tissue, or according to the method of Lazo \& Quinn.(9), which utilizes a $30 \mathrm{mmol} / \mathrm{l}$ solution of octyl- $\beta-D$-glycopyranoside.

\section{Agar gel electrophoresis}

After centrifugation at $50000 \mathrm{~g}$ for $30 \mathrm{~min}$ at $4^{\circ} \mathrm{C}$, the supernate of the homogenized tissue was used for electrophoresis. Agar gel electrophoresis was carried out as described by Wieme (10). Protein and enzyme electrophoresis was performed on microscope slides $(2.5 \times 7.6 \mathrm{~cm})$ covered with $1 \mathrm{~mm} 10 \mathrm{~g} / \mathrm{l}$ agar gel in a $0.04 \mathrm{~mol} / \mathrm{l}$ sodium barbital $0.09 \mathrm{~mol} / 1 \mathrm{HCl}$ buffer $\mathrm{pH}$ 8.4). Migration time was $25 . \mathrm{min}$ at $140 \mathrm{~V}$. Along with the sample, $3 \mu \mathrm{l}$ of a mixture of human albumin $(10 \mathrm{mg})$ and Macrodex $(0.2 \mathrm{ml})$ in $1 \mathrm{ml}$ sodium barbital- $\mathrm{HCl}$ buffer was applied below the sample application site.

After electrophoresis the region between the migration points of albumin and Macrodex was cut into 10 slices. This distance was taken arbitrarily as one unit (1.00), and the relative mobility $\left(\mathrm{m}_{\mathrm{r}}\right)$ of the detected enzymes assigned accordingly.

\section{Polyacrylamide gel electrophoresis}

Disc electrophoresis of tissue homogenates was carried out by the procedure of Maurer (11).

Glass tubes $(0.6 \times 85 \mathrm{~mm})$ were utilized and the gel consisted of $75 \mathrm{~g} / \mathrm{l}$ acrylamide, $2 \mathrm{~g} / \mathrm{l}$ bis-acrylamide in a $0.08 \mathrm{~mol} / \mathrm{l}$ tris(hydoxymethyl)-aminomethane $0.16 \mathrm{~mol} / 1 \mathrm{HCl}$ buffer ( $\mathrm{pH}$

7.5). The electrode buffer solution ( $\ddot{p} H$ 7.0) consisted of 0.3 mol/l diethylbarbituric acid-0.01 mpl/1 Tris. Bromophenol blue 
was used as a tracker dye. Electrophoresis was performed at constant current $(2.5 \mathrm{~mA})$ per tube. After electrophoresis the gel was cut into 15 equal parts, between the migration point of albumin and the top of the gel.

\section{Enzyme detection}

Each slice of gel was incubated $16 \mathrm{~h}$ at $37^{\circ} \mathrm{C}$ in a tube containing $0.5 \mathrm{ml}$ incubation mixture, consisting of $10 \mathrm{mmol} / \mathrm{l}$ substrate, ( $p$-hydroxybenzoyl-Gly-L-His-L-Leu), $3 \mathrm{kU} / 1$ hippuricase and $2.5 \mathrm{mmol} / \mathrm{l}$ 4-amino-antipyrine in a $0.12 \mathrm{~mol} / \mathrm{l}$ borate buffer ( $\mathrm{pH} 8.3$ ) containing $0.7 \mathrm{~mol} / \mathrm{l}$ sodium chloride.

After the incubation, $1.5 \mathrm{ml}$ of a stopper and developer solution containing $\mathrm{NaIO}_{4} \quad 6.5 \mathrm{mmol} / \mathrm{l}, 3 \mathrm{mmol} / \mathrm{l}$ ethylenediaminetetraacetic acid and $2 \mathrm{~g} / \mathrm{l}$ Triton $\mathrm{X}-100$ was added to each tube. The colour intensity produced by the quinoneimine dye was measured at $505 \mathrm{~nm}$ with a Beckman model $25 \mathrm{spec}-$ trophotometer.

Detection of catalytic activity was carried out as follows:

\begin{tabular}{|c|c|c|}
\hline $\begin{array}{l}p \text {-hydroxyhippuryl- } \\
L \text {-His-L-Leu }\end{array}$ & $\begin{array}{c}\text { angiotensin- } \\
\text { converting enzyme }\end{array}$ & $\begin{array}{l}p \text {-hydroxyhippuric } \\
\text { acid }+L \text {-His- } L \text {-Leu }\end{array}$ \\
\hline p-hydroxyhippuric acid & hippuricase & $\begin{array}{l}p \text {-hydroxybenzoic acid } \\
+ \text { glycine }\end{array}$ \\
\hline $\begin{array}{l}\text { D-hydroxybenzoic acid } \\
+ \text { 4-amino-antipyrine }\end{array}$ & $\mathrm{NaIO}_{4}$ & \\
\hline
\end{tabular}

The specificity of the reaction sequence for angiotensin-converting enzyme was tested by adding $0.1 \mathrm{ml} 1 \mu \mathrm{mol} / \mathrm{l}$ captopril to each incubation tube. Controls run with no enzyme ảnd substrate did not give any colour. For each biological fluid or tissue, at least two specimens from different patients were examined.

\section{Results}

Since the same sample volume $(7 \mu \mathrm{l})$ was employed for each determination, the electrophoretic procedure provides a relative estimation of the converting enzyme catalytic activity in the various tissues and fluids examined. The enzyme appears widespread, but the amount of catalytic activity differs widely, depending on the type of tissue examined.

The results obtained by agar gel electrophoresis are represented in figure 1, (a to j). For the sake of clarity, the results are shown in groups of low and high enzyme activity.

Tissue homogenates with very high enzymatic activity are diluted before electrophoresis with physiological saline.

Benign prostatic hyperplasia has the highest angiotensin-converting enzyme activity of all the samples studied. Its major converting enzyme activity migrates in agar gel with $a m_{r}=0.75$. This is also the $m_{r}$ of the enzyme from prostatic fluid and of one of the two peaks of seminal plasma. The latter also has a very active component with $\mathrm{m}_{\mathrm{r}}=0.45$, coinciding with the $\mathrm{m}_{\mathrm{r}}$ of the converting enzyme of seminal vesicles. Further differences are exhibited by the enzyme from other tissues of the urogenital tract: converting enzyme from kidney and bladder migrates at $\mathrm{m}_{\mathrm{r}}=0.55$.

The enzyme from the tissues of the digestive tract, e. g. sigmoid and stomach, also migrates differently from those described above. The lower angiotensinconverting enzyme activity in normal prostate and prostate cancer than in benign prostatic hyperplasia is remarkable, but the enzyme activities have the same $\mathrm{m}_{\mathrm{r}}$. In some tissues, an additional converting enzyme activity was found, which moved slowly $\left(m_{\mathrm{r}}=0.15\right)$ and showed a relatively small amount of enzymatic activity.

Compared with agar gel, polyacrylamide gel electrophoresis has a high resolving power for proteins, particularily when a stacking gel is used. However, the use of a stacking gel did not improve the enzyme separation. The polyacrylamide gel results obtained from some tissues are represented graphically in figure 2. The patterns obtained are quite similar to those obtained by agar gel electrophoresis. However, one major difference is the enzymatic activity which remains either in the stacking gel, or in the sucrose solution in which the sample is added to the separating gel. The nature of this phenomenon is not clear, but presumably this could be due to enzyme aggregation. Addition of $0.1 \mathrm{ml} 1 \mu \mathrm{mol} / 1$ captopril to each incubation mixture completely inhibits the angiotensin-converting enzyme activity found in the majority of tissues. Residual activity was detected only in the stomach and the ileum tissue (fractions of 0.10 and 0.22 respectively).

The $m_{r}$ of fractions from the same tissue are always identical..For example (fig. 1), the major converting enzyme activity for benign prostatic hyperplasia $(n=$ 5) was always detected at $m_{r}=0.75$. The same $m_{r}$ was also found for normal prostate $(n=2)$ and prostatic adenocarcinoma $(n=2)$.

The reproducibility of agar gel electrophoresis made it possible to locate the enzyme activity bands without staining the gel. Slices containing the enzyme activity were cut out of the gel and resubmitted to electrophoresis in another agar gel plate. After the second electrophoresis, the gel was cut again into slices and assayed as described above.

The same electrophoretic pattern as the original was always obtained from an excised fraction, which proves that each fraction found is a single component. 




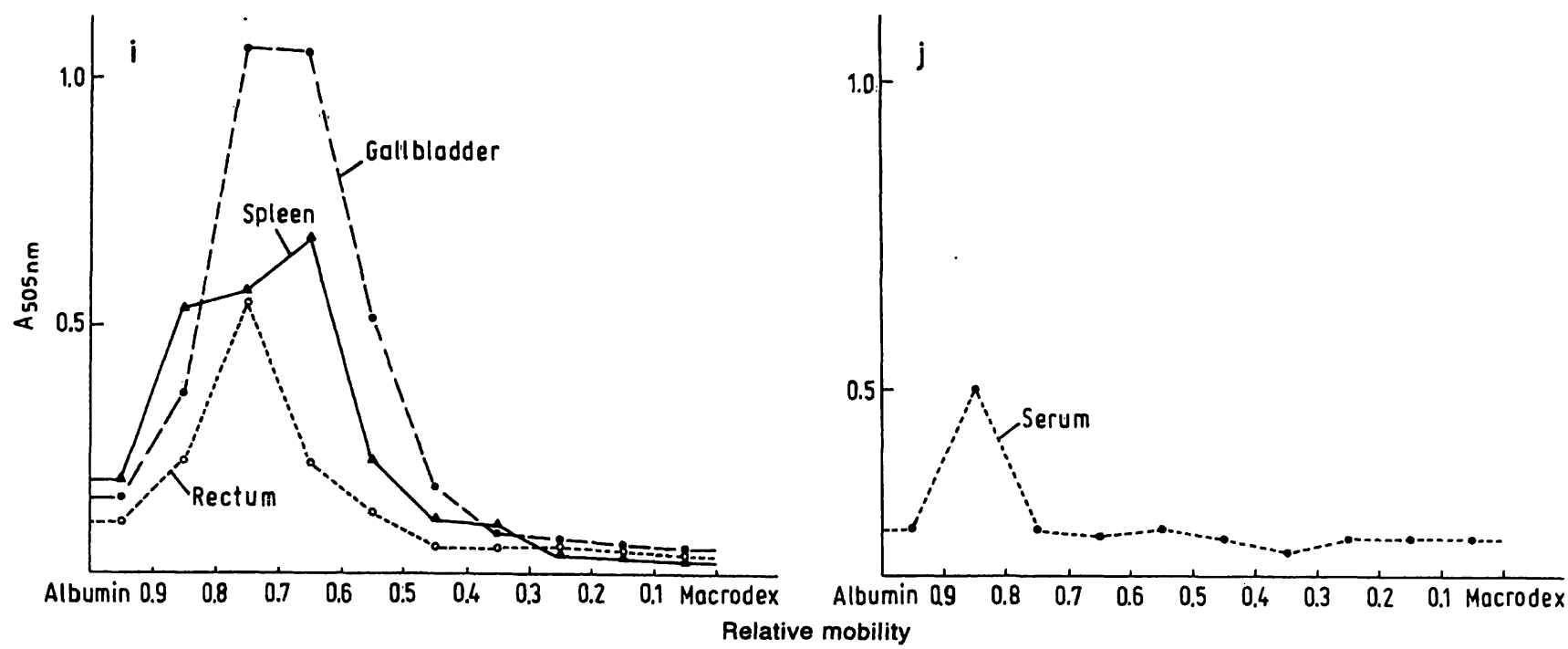

Fig. 1 (a to j). Electrophoretic behaviour of angiotensin-converting enzyme in different human body tissues and fluids. Details are described in the Methods Section. Ordinate: absorbance (A). Abscissa: mobility $\left(m_{r}\right)$ relative to albumin $\left(m_{r}=1\right)$ and Macrodex $\left(m_{r}=0\right)$.

The long incubation time could be the origin of some artefactual results. In order to exclude the effects of other proteinases on the substrate, we added several proteinase inhibitors to the incubation mixture (12). The following proteinase inhibitors were used: Soybean trypsin inhibitor $(100 \mathrm{mg} / \mathrm{l})$, N-ethyl-

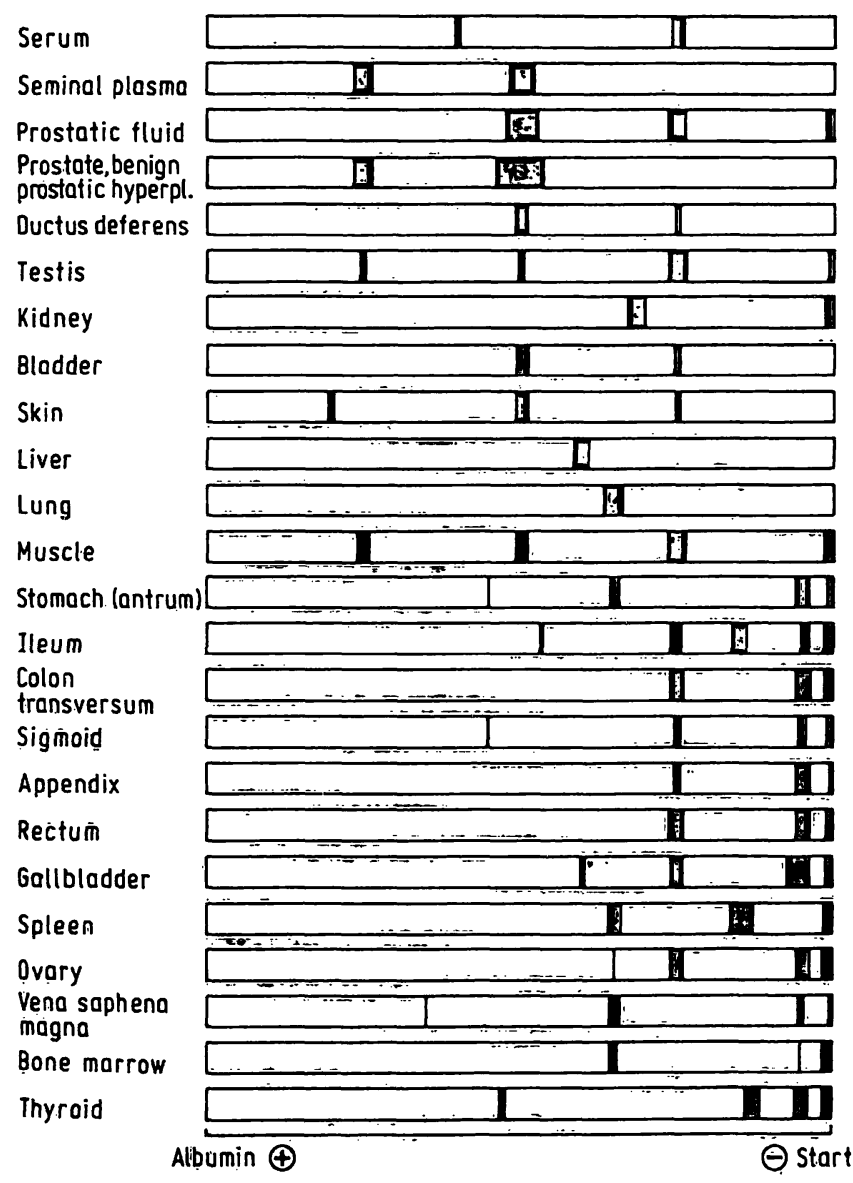

Fig. 2. Schematic representation of polyacrylamide electrophoretic patterns of angiotensin-converting enzyme. Enzymatic activity found is represented by the blocks. Details are described in the Methods Section. maleimide ( $2 \mathrm{mmol} / \mathrm{l})$, pepstatin $(1 \mathrm{mg} / \mathrm{l})$ and aprotinin (2000000 Kunitz inhibitor units per litre). There was no influence, on the enzyme pattern. Aprotinin also inhibited the activity of converting enzyme of stomach by $39 \%$, testis enzyme by $10 \%$ and sigmoid enzyme by $5 \%$, without changing the $\mathrm{m}_{\mathrm{r}}$ of the enzyme.

In agar gel, electrophoretic mobility is in the first instance related to the electrical charge of the molecule. Thus the differences found in $\mathrm{m}_{\mathrm{r}}$ for converting enzyme in the tissues and fluids studied may be a function of the number of sialic acid groups in the angiotensin converting enzyme molecule.

\section{Discussion}

The method used for detecting the converting enzyme activity in the electropherogram has several advantages: the red quinoneimine dye, which is formed, gives a qualitative and quantitative estimation of the enzymatic activity present in the agar gel or polyacrylamide slices. The detection method has been developed for the quantitative estimation of angiontensin-converting enzyme in human serum (2) and results obtained correlate well with the Cushman \& Cheung (13) technique.

The applicability of the method for experimental purposes has been demonstrated.

The study of angiotensin converting enzyme in crude tissue homogenates is complicated by the presence of other proteolytic enzymes. But available evidence suggests that the two criteria used for. detecting and classifying converting enzyme truly distinguish this enzyme from other known aminopeptidases, 
peptidylpeptidases and proteases. The cleavage of the histidyl-leucine dipeptide from an artificial substrate (p-hydroxybenzoyl-glycyl- $L$-histidyl- $L$-leucine) has been accepted for the determination of converting enzyme activity since the pioneer studies of Cushman \& Cheung (13). As far as we know, the second criterion used, namely the inhibition of the enzymatic activity by captopril in low concentration, has only been described for angiotensin-converting enzyme (14).

In order to study the multiple forms of angiotensinconverting enzyme activity, other proteases were inhibited with various inhibitors, and the inhibition of converting enzyme activity by captopril was

\section{References}

1. Lieberman, J. (1975) Am. Rev. Respir. Dis. 120, 329-335.

2. Kasahara; Y. \& Ashira, Y. (1981) Clin. Chem. 27, 1922-1925.

3. Fitz, A. '\& Overturf, M. (1972) J. Biol. Chem. 217, $581-584$.

4. Depierre, D. \& Roth, M. (1974) Experientia 30, 686.

5. Oshima, G., Ganasana, K. \& Kato, J. (1976) J. Biochem. $80,479-483$.

6. Litrowicz, A. \& Malofiejew, M. (1978) Biochem. Pharmacol. 27, 2829-2834.

7. Grönhagen-Riska, A. C. \& Fyhrquist, F. (1980) Scand. J. Clin. Lab. Invest. 40, 711-719.

8. Hara, A., Fukuyama, K. \& Epskin, W. L. (1981) Clin. Chim. Acta 117, 269-277. exploited. Using similar conditions, we developed two reliable techniques for determining the electrophoretic behaviour of angiotensin-converting enzyme. In several human tissues and fluids, the enzyme can be resolved into two or more fractions with distinct electrophoretic mobilities.

\section{Acknowledgement}

We are highly indebted to Prof. Dr. A. Hubens and $K$. Van Camp and also to Drs. J. Bultinck, C. Van Camp and $R$. Van Hee for providing tissues. We gratefully acknowledge indebtedness to Prof. G. Hatfield for helpful discussion, and to Mrs. E. Enödi and Mr. E. Cuypers for skilful technical assistance.

9. Lazo, J. T. \& Quinn, D. E. (1980) Arch. Biochem. Biophys. $102,68=71$.

10. Wieme, R. J. (1965) Agar Gel Electrophoresis, Elsevier, Amsterdam.

11. Maurer, H. R. (1968) Disc electrophoresis, pp. 42-43, de Gruyter, Berlin.

12. Werb, Z. (1981) In: Methods for Studying Phagocytes (Adams, D. D., Edelson, P. J. \& Koren, H. S., eds.), p. 563, Academic Press, New York.

13. Cushman, D. W. \& Cheung, H. S. (1971) Biochem. Pharmacol. 20, 1637-1648.

14. Skidgel, R. A., Engelbrecht, S., Johnson, A. R. \& Erdös, G. (1984) Peptides 5, 769-776.

Prof. Dr. S. Scharpé

University of Antwerp, UIA

Universiteitsplein 1

B-2610 Wilrijk 